\title{
Irregular migration and coping strategies of undocumented migrants: A qualitative perspective from irregular returnees in Lagos State, Nigeria
}

\author{
Kennedy Eborka ${ }^{1}$ and John Lekan Oyefara ${ }^{2}$ \\ ${ }^{1}$ Department of Sociology, University of Lagos, Nigeria \\ keborka@unilag.edu.ng \\ ${ }^{2}$ Department of Sociology, University of Lagos, Nigeria
}

\begin{abstract}
This study examined the dynamics of irregular migration and coping strategies of irregular migrants among irregular returnees in Nigeria. The aim was to understand the patterns of irregular migration, coping strategies of irregular migrants, and condition of homeland among irregular returnees. The study adopted the non-experimental research design and used qualitative tools to capture important nuances, impressions and anecdotes from thirty-eight (38) respondents in Lagos State. Data were gathered by Indepth Interviews (IDIs) and analyzed through manual content analysis. Results indicate that economic factors tend to influence irregular migration, especially among those who go by land; while a number of migrants in irregular situation adopt different strategies such as changing their real names and engaging in underground jobs in destination places to cope. Furthermore, many irregular returnees were unable to acquire useful skills or raise capital during their stay; this made efforts towards self-improvement and contribution to homeland development difficult.
\end{abstract}

Keywords: Nigeria, deportation, irregular, migrants, returnees.

\section{Introduction}

Recent time has witnessed a dramatic change in international migratory movements towards more irregular patterns of migration, especially from developing countries to the more developed countries of the world. As a concept, irregular migration describes migratory movements whereby migrants travel across international borders into other countries without legally valid documents and official permission. In most cases, these movements involve clandestine and complex routes (Global Commission on International Migration [GCIM] 2005, Adepoju \& Van der Wiel 2010, Bloch \& Chimienti 20I2). This pattern of international migration became more noticeable as a global phenomenon at the dawn of the twenty-first century and occurs more in developing countries. Though the surreptitious and undocumented nature of irregular migration makes a reliable data on its scale difficult, in 2014, it was estimated that between 10 and 15 percent of global migrants were in irregular situation (International Organization for Migration [IOM] 20I5).

In Nigeria, while there is paucity of official and reliable data to establish the level of irregular migration in the country, information from destination countries and international agencies working to help migrants in irregular situation indicates that Nigeria is a major originating spot of irregular migration (IOM 2015). For instance, between January and April 2015, more than I,800
African migrants on irregular routes perished in Mediterranean ship mishaps trying to enter Europe, while about 8,500 were rescued. Many of these figures were said to be from Nigeria (IOM 20I5); and this did not include movements to the Americas, Asia and the Middle East; the latter two constituting some of the new destinations in international migration flow from Nigeria. Efforts at managing and repressing this phenomenon by most receiving countries tend to push irregular migrants to device more complex strategies and diversify destinations. Thus, rather than curbing the trend, attempts to discourage it had intensified migrants' determination to follow more irregular routes often leading many of them to uncertain end.

This phenomenon has important development implications for Nigeria. The shrinking workforce occasioned by continuous massive outflow of young people will rob the country the essential manpower needed for socio-economic development. Although it is sometimes argued that international migration opens opportunity for countries with excess labour to contribute migrant workers who will send remittances for the development of home country, in the long run however, migration will not be able to offset the economic impacts of the declining labour force in sending countries (Levitt \& Lamba-Nieves 20I3). This is more so for irregular migration with all its uncertainties. Thus, a systematic assessment of 
this phenomenon will have relevant policy implications for realizing important Sustainable Development Goals (SDGs) at both the individual and societal levels.

\section{Objective of the Study}

There are still varying and inconsistent perceptions on the patterns, scale, causes and consequences of irregular migration, as reflected in public opinion. This study is an attempt to contribute to clarifications on the dynamics of irregular migration. More specifically, it will concentrate on the following research questions:

I. What are the modes of movement in irregular migration in Nigeria?

2. How do migrants in irregular situations cope in destination country?

3. What is the situation of irregular returnees on coming home?

\section{Brief Literature Review and Theoretical Framework}

Earlier interests in migration in Nigeria focused on the more general nature of migration and created distinctions on migration history in the country viz., Hausa transnational links via trans-Sahara trade route on pilgrimage to Mecca; the trans-Atlantic slave trade; migration within Nigeria during the colonial period; intra-regional migration within Africa; and international migration of Nigerians across the continent of Africa to North America and Europe (Federal Republic of Nigeria [FRN] 20I3). Therefore, as a phenomenon, migration has always been a part of the Nigerian reality, varying only in patterns and degrees.

Initially, the fifth aspect in the foregoing distinctions (i.e., international migration) coincided roughly with the late colonial era and early independence period, with the flows or movements directed towards the United Kingdom (UK) and some to the United States of America (USA). With regard to these periods, record suggests that the current was low and those who travelled went for the purpose of further studies, and many of them returned to participate in the nation-building process of the country after their studies (Kalu 2008). However, this pattern was to change years later. A number of economic, political and social conditions combined to ignite unprecedented waves of international migration in Nigeria. This period marked the beginning of the tendency of many Nigerians to shun home coming and the inclination to remain abroad increased (Pennington \& Balaram 2013).

In response to the growing wave of immigration, many host countries intensified attempts to manage migration by introducing tough immigration policies and tightened border security to discourage indiscriminate mass inflow. These developments meant that legal migration became more difficult and limited to the privileged few. Consequently, many young people in developing nations desperate to leave their countries began to patronize irregular routes and diversified destinations to include countries in East Asia and the Middle East (MajaPearce 2009, Lucas 2005, Bloch \& Chimienti 20/2). In all events, irregular migration has become an issue of serious public concern for both state and non-state actors such as governments of destination countries, human rights campaigners, employers who exploit the vulnerable state of irregular migrants for cheap and compliant labour, and the migrants themselves who endanger their lives (IOM 2008).

As earlier indicated, migration in general has received robust research attention by scholars interested in interpreting the consequences of migratory movements on the economic and sociodemographic statuses of sending and receiving communities (United Nations 200I, Jokisch 2002, Iversen 2005, Miluka et al. 2007, World Bank 2007, Bertoli 2008, Gray 2009, Oucho 2010, Adepoju \& Van der wiel 2010, Adepoju 2010, Campbell \& Barone 20I2, Eborka 20I4). However, there is not much to show that the phenomenon of irregular migration has been given sufficient systematic research attention in Nigeria. Existing literature on the phenomenon focused on the more general aspect of irregular migration such as the scale, the strategies to manage it in destination countries, immigration and border management challenges, as well as return and reintegration issues among others (IOM 2008, Bloch \& Chimienti 2012, Pennington \& Balaram 2013). Except for these generalized reports and opinions, there is very little systematic attempt to understand the nature of irregular migration in Nigeria from the perspectives of the migrants themselves.

Return irregular migrants fall into the category of populations usually referred to as the "hard-to-reach" or "hidden" populations. They are hard to reach because they are not easy to identify from the general population. Consequently, literature on the phenomenon in Nigeria is not quite clear on the patterns and dynamics. For instance, what are the coping strategies as males or females migrants in irregular situation? Do men, for example, engage in male sex work to survive as Castaneda's (2014) study on male migrants in Germany revealed? It is assumed that international migration is intrinsically positive in relation to migrants' development in terms of skill acquisition, capital accumulation and overall improvement of migrants' wellbeing and society (Farrant et al. 2006; Lucas, 2005). It has also been 
argued that remittances from migrants and the presence of returnees tend to raise the social status of their families in origin places (Gilbson, Mckenzie \& Stillman 2009). How true are these hypotheses in relation to irregular migration in Nigeria?

\section{Theoretical Framework}

The historical realization of the significance of migration in the life of a society made attempts at theoretical elucidation on its propellants inevitable. One of the earliest efforts at theoretical systematization in the field of migration theory was by the German geographer, Ernst George Ravenstein (1889) and pursued further by Everette Lee (1966) who inspired the formulation of the "pull-push" factors of migration. The premise of this argument is that the migration process is governed by negative and positive factors, with people's expectations constituting the intervening variables. That is, the decision to migrate tended to be based on the rational calculus of the individual on the conditions or opportunities in origin places, relative to conditions and expectations in the prospective destinations. Essentially, this theoretical approach, represented as the classical school, holds the view that push-factors such as unemployment and difficult life situation in origin places push people to leave such areas; while pull-factors in form of the existence of opportunities with potentials for social and economic enhancements in other places pull or attract people to such areas.

Though this submission had been lauded for pointing out the role of lack of opportunities in origin places as propellant factors for emigration and outmigration (De Haas 2008, Abreu 20l0), it appears to have been silent on the forces propelling certain categories of migrants. For instance, if it is the lack of opportunities for social and economic enhancements that pushes people to leave an area, people from apparently established socio-economic background and high social standing should be insulated from this push. However, observational findings and anecdotal evidence indicate that a significant number of the emigration flow from Nigeria involved people who, by virtue of their backgrounds, are not lacking opportunities. Nonetheless, the push-pull hypothesis held sway in migration theorizing until the emergence of the Historical-Structural School, which will follow in a short while.

Thus, while Ravenstein and his colleague might not have formulated their theory specifically with irregular migration in mind, the theory appears useful in gaining some insights on some propellant factors of irregular migration such as lack of opportunities for self socioeconomic enhancements. To that extent, irregular migration could be said to be related to structural determinants in both sending and receiving countries. That is, migrant-receiving countries need cheap labour offered by irregular migrants, while sending countries have the tension created by underemployment, inequality, political, social and economic uncertainties that force young people away from home.

On the other hand, the Historical-Structural approach to migration represents a body of theoretical pronouncements that emphasizes structural demand for migrants' labor in advanced capitalist societies, as well as the migration-inducing effect of the penetration of capitalism in peripheral socio-political formations (Sassen 1991). The approach still suffers similar limitation observed in the Classical School given that both could only explain an aspect of the migration process. In that regard, the adoption of the New Economics of Labor Migration (NELM) and Campbell and Barone's (20I2) personality perspective of migration is imperative to supplement the explanatory strengths of the Classical and Historical-Structural Schools.

The NELM posits that migration, particularly international migration, is part of the household's economic strategies. While it does not deny the existence of structural constraints implied in the pronouncements of the Classical and HistoricalStructural Schools, it supposes that in recent history, international migration in many cases is embarked by individuals as a strategy arising from family decision to counter conditions that pose threats to family's socioeconomic standing and wellbeing. On the other hand, Campbell and Barone postulated that certain personality type, what they called the mobiocentric personality type: people who value action and motion, and are prone to always be on the move; are more likely to migrate. The thrust of the theory is that, some individuals are inclined to be on the move or always migrate because of their personality characteristics (Cambell \& Barone 20I2).

By way of synopsis, while the last word on the propellant factors of migration might not have been said, the synergistic theoretical orientation adopted in this study, no doubt, has illuminated some blurred areas that would have continued to puzzle theoretical imaginations had the paper not adopted a multidimensional theoretical approach. Drawing from the foregoing theoretical expositions, it could be said that irregular migration is a response to negative home conditions pushing people away from origin places to areas that present opportunities for self development, on the one hand; as well as the outcome of family's strategy to overcome unfavourable economic conditions that threaten family's survival on the other hand. 


\section{Materials and Method}

The nature of the subjects under investigation makes it imperative to adopt approaches different from those commonly used in research on more easily observable population, such as quantitative manipulation and extrapolation of data. Thus, the method was non-experimental and essentially qualitative. The study relied mainly on In-Depth Interview (IDI) for collection of data. The interviews were done in English language because all the respondents could speak English. Their voices were recorded after obtaining their consent and permission. This was later transcribed, and quality control was ensured by listening to the audio and comparing it with the transcript to make sure that the actual words of subjects were captured.

\section{Study Location and Population}

The study was carried out in Lagos State, Nigeria, between June 30 and September 29, 20I5. The state is one of the 36 states in Nigeria and located in the Southwest geopolitical zone which is dominated by the Yoruba ethnic group. The state has twenty constitutionally recognized local government areas with thirty-seven local council development areas (LCDA) created by the government of the state. Lagos State represents the commercial hub of Nigeria and was the country's capital until 1991 when Abuja became the country's capital city. The study population consisted of return irregular migrants in Lagos State.

\section{Sampling Technique and Method of Analysis}

The non-probability sampling technique was adopted for selection of study participants. This involved purposive, referral and snowballing sampling techniques. The latter meant that the researchers were unable to exercise absolute control on where to conduct IDI for respondents selected through snowball. In some cases, an encounter with a purposively selected respondent would snowball into the selection of another participant residing in a different local government area. The study involved forty participants as its sample size, but only thirtyeight were eligible for inclusion in the study. This amounted to about 95 percent response rate. Eligibility criteria for return irregular migrants included respondents who have been around for up to one year, and whose mode of travelling was irregular (Adepoju \& Van der Wiel, 20I0, IOM 20I2). Thus, returnees who have not spent up to one year on return, and those who might have spent up to one year, but did not spend up to a year abroad, were not included in the study. In all, twenty-three males and fifteen females were interviewed during the study.
Qualitative data generated from the study were analyzed through manual content analysis.

\section{Ethical Consideration}

Ethical considerations were strictly emphasized during the fieldwork. The nature and objective of the study did not pose any risk to subjects. Thus, there was no need to obtain approval from Institutional Review Board (IRB). Throughout the study, confidentiality protocols were observed and participation was voluntary and based on informed consent.

\section{Study Results:}

Modes of movement in irregular migration

Crossing international border illegitimately by migrants takes many forms in Nigeria. It may involve employing various guises including tendering forged documents to obtain official permission to travel on grounds of false contract marriages to citizens of envisaged destination country, disguising as tourist, international student or conference delegate. Another means involves following complex and often dangerous routes especially across the Maghreb to Europe. The study attempted to understand what determine the means adopted by migrants in embarking on irregular migration. In the responses gathered from respondents to the question on what determine the means adopted, majority reported that financial status is central to the process a migrant follows. According to one study respondent who was deported from Spain:

It is the money you have that will determine the means you follow. By land will cost you about three hundred and fifty thousand naira to reach Spain. But if you want to go by air, they will collect one million naira. So, is the money. If you paid the three hundred thousand and succeed, it is the same Spain that you will enter with the person that travelled by air; although it takes more days and very risky to go by land. In fact, some people die on the way and some cannot cross because of fear. Many of us follow land because is cheaper, although more dangerous. But life is about risk. You look at those who succeeded and encourage yourself (IDI/24/0820/5/male returnee from Spain).

Another respondent (a female returnee from Malta) gave a similar account on the role of economic strength on mode of irregular migration. According to her:

I decided to go through land because I could not pay the fees to go by air. Actually, that was the 
reason I later travelled to Malta. I was supposed to travel to Norway, but the money was too much for me. But unfortunately, I was among those deported in 2005 when many Nigerians in Malta were repatriated. We were told that Nigerian government then said Nigeria had improved and that the government of Malta should send us back to work in Nigeria. That was how many of us were deported (IDI/25/08/I5/returnee from the Republic of Malta).

\section{Perspectives on reasons for emigration}

Some factors have been adduced in migration literature as reasons for emigration by many African irregular migrants, with particular reference to Nigeria. Responses from the majority of the study participants tend to corroborate a segment of existing thinking which points to the need for improvement in economic condition as a major reason for migration; even among migrants from economically established backgrounds. For instance, one double deportee (first from Germany and then Belgium) revealed thus:

After I graduated from university, I spent five years without any job. To survive, I picked up okada and was able to raise some money. It was the money I spent to travel to Germany; but I was deported after spending about a year and some months in Germany. While I was in Germany, I had no paper so I could only do night work and was able to send some money back to Nigeria before I was deported. When I came back to Nigeria, I used the money to do another visa and travelled to Belgium, but I was also deported after six months from Belgium. So, when you see people leave Nigeria, is because of frustration (IDI/28/08/I5/returnee from Belgium).

When asked why he did not use the capital generated from okada - the use of motorcycle as a means of transportation, now a major means of livelihood among many Nigerians - to invest in Nigeria instead of travelling to Europe, the respondent stated as follows:

There is no hope in Nigeria. The country is too frustrating for small businesses to survive. What are you going to invest in without enough money? Things are too expensive. Before you pay for shop with all kinds of illegal charges landlords collect; settle Area Boys and do other necessary things, the money for the actual business would have reduced seriously or finished. My plan was to travel, work and raise enough capital and come back to invest in hotel business. But unfortunately, it didn't work out as planned (Ibidem).
The foregoing response points to the difficult investment environment faced by many small scale businesses and those intending to go into small scale business. Beyond the huge cost for securing business space, there are other associated arbitrary charges by landlords which make attempts into small scale business by people without much capital frustrating. This is besides the activities of Area Boys: A ubiquitous group of street urchins found in most areas of Lagos State, who live by intimidating and extorting money from small scale business owners in many parts of the state unchallenged. The foregoing revelation has made the need for more government's actions in protecting small scale business owners and proper implementation of policies on tenement issues.

Nonetheless, there is evidence to suggest that not all who migrated were pushed by lack of employment. This indicates that there are possibly other reasons outside lack of employment opportunities that motivate people to migrate. Hear one returnee from the United Kingdom:

I was working in a bank in Nigeria before I travelled. My initial plan was to relocate abroad. But when I got there, it was difficult to find a good job like the one I had in Nigeria. When I saw that things were not the way I expected, I quickly applied to take a Master's degree and returned to Nigeria after my programme (IDI/03/09/I5/returnee from the United Kingdom).

Perspectives on skills/capital acquired in destination countries and mode of return

Responses obtained from the study's respondents on capital and skills acquired during their travel suggest that the ability to acquire new skills depends on the circumstances migrants find themselves in host country, intention for emigration and destination region. A male returnee from Germany revealed thus:

Life abroad is difficult without legal permit to work and move around. Before you can be able to learn a new skill, you must be free to move around and look for where to get new skills. Some of us know what we went through because of lack of permit when we have overstayed our visas. You cannot come outside without paper because if you are caught, you will be repatriated. To survive, the person you are staying with can help you get a sponsor who can help you get underground job until you are able to get your papers (IDI/30/08/I5/returnee from Germany). 
A similar situation is observed from the responses of a male returnee who travelled to the United States of America (USA) in 1988. According to him:

I wanted to go to school, but things were not easy with me in the USA. It was difficult to get my paper which could have enabled me to stabilize myself. All I could afford were menial jobs such as in restaurants. In 2004, I was detained and deported after some months by the US Immigration and Custom Enforcement. I have children there but I was sent back without my children (IDI/02/09/I5/returnee from the USA).

Furthermore, patterns of responses from study participants suggest that the ability to gather capital for investment in homeland is related to circumstances in destination and mode of return. Majority of those who were deported (involuntary returnees) after incarceration for various immigration offences had little or no capital to invest on return. For instance, a male returnee from Germany noted as follows:

I was in the Western world for seven years. I was detained after two years of arrival and subsequently deported. I did not come back with anything. The situation in Europe is bad when you have no paper. Once you are found, you are not allowed to pick anything you have acquired there, unless you have been able to send things home. I found casual job after three months of arriving in Germany. The job was not stable, so I had to do whatever came my way to survive and sent some money and items home. But I was later arrested and detained. I thought they would leave me after all the time I spent in detention, but the next thing was deportation. When I returned, even the little money and items I sent could not be accounted for. That was another frustration. My people mismanaged everything. What saved me was that I have a B.Sc. degree in History in Nigeria before travelling. That is what I am now using to teach at a private school. If I knew, I would have stayed back in Nigeria and further my education, instead of going to Europe where my life was almost wasted (IDI/I8/08/I5/Germany).

Considering that a significant number of them gave economic hardship as the reason for migrating, questions were raised to probe how migrants who were supposedly trying to escape socio-economic impoverishment were able to fund the huge cost charged by irregular migrants smugglers. A male respondent from Russia revealed thus:
I have OND and was without job for about five years after my IT. I didn't want to go back for my HND because of the way they discriminate the certificate; and getting admission into the university was difficult. I had to talk to my father about traveling abroad. He agreed and sold parts of his landed property. That was how we raised money. But I made a mistake to go to Russia; is difficult to survive there. I didn't come back with anything. It was my father who raised some money for me to start the business I am into now (IDI/20/08/20I5/returnee from Russia).

Similarly, a male voluntary returnee from South Africa stated that his family raised fund through mortgage from a money-lender to travel to Germany. The original plan was to offset the loan from the remittances he would send and take back their building, but he was taken to South Africa by the agent instead of Germany as agreed. His words:

I am a graduate of geology. After three years without job, we thought that I could travel as others were doing. My senior sister introduced one of their church members to us whom she said was into visa business. The man gave us 100 percent assurance of my successful travel to Germany. My father then went and borrowed money from a money-lender and surrendered his only building as security. Rather than do as agreed, the man arranged for me to be taken to South Africa and informed us that it was safer to enter Germany through South Africa to avoid deportation. On getting to South Africa, he started giving excuses and said I should try and stay in South Africa, that the place is good. That was when I realized that I had been deceived. I had to come back because there was nothing to hold on to in South Africa (IDI/29/08/20I5/returnee from South Africa).

When he was asked about what happened to the mortgage, he responded that the money-lender took possession of the building; but expressed hope that they will get it back some day.

Nonetheless, there is evidence from the responses among some returnees to suggest that some remittances had been made with which they invested in the country on return.

\section{Coping strategies of irregular migrants in destination places \\ The study attempted to understand how irregular migrants cope in destination countries considering their illegal situations. Immigration policies in some countries make it extremely difficult for irregular migrants to settle. Very often, they have no access to welfare and public space (Van de Valk 20l0). This}


raises question on how they cope in destination countries, and to what extent they are able to integrate in the receiving destination. Responses to probing questions on this revealed that irregular migrants adopt a number of strategies to cope until they are able to regularize their stay if they are fortunate to continue to evade deportation before the regularization. A female participant revealed that one of the ways is to change name. Hear her:

Many of us don't bear our names once we get there. You have to change it so that they will not know where you come from. Is like they don't like Nigerians, although is not only Nigerians that change their names. You have to change it in case they are looking for the person with your name, they will not be able to detect who you are or where you come from easily (IDI/26/08/I5/returnee from Spain).

When the participant was probed further on what they do to survive, given that they are unable to move freely; she responded thus:

We hustle. You do what others are doing to survive, at least for that first time. If you are lucky, you will meet somebody that will help you (ibid.).

The use of the term "hustle" to describe what some migrants in irregular situation do to subsist made it difficult to capture the actual activities they engaged in. However, responses from a male returnee from Germany to a probing question on how he survived as an irregular migrant before he was deported gave some insights into some surviving strategies. He said:

First, it depends on where you find yourself. The people you meet can introduce you into what they are doing. Some can ask you to wait and help you get a job later. But when your visa expires, you cannot come outside easily. To survive, the person you are staying with can introduce you to a sponsor who can help you get underground job on agreement to pay certain amount from what you make. But some of them are wicked and can report you to immigration if you refused on the basis of the amount they demand from what you may earn. You have to be careful when you come across them (IDI/30/08/I5/returnee from Germany).

Furthermore, the kind of job done to cope could be gleaned from a returnee's response to a question on how he managed to survive:

Things were not easy. I did all kinds of menial jobs that came my way, but they were not stable. I was frequently getting in and out of menial jobs, especially restaurants and bars. Sometimes, we get some dash from people who visited there (IDI/02/09/I5/returnee from the USA).

The foregoing responses give the picture of the complex situation that irregular migrants face in trying to survive in destination places. Respondents who were unwilling to provide information on their coping strategies simply noted that they hustled; a term that suggests the lack of definite and dignifying mode of economic engagement and survival in destination countries.

\section{Situation of irregular returnees on coming home}

There is a near unanimity among the study respondents on the inhospitable socio-economic and political environment back home in Nigeria. Even responses from returnees who suffered detention and maltreatment in their various destination countries before repatriation indicated that they would have preferred to remain in their host countries had they been able to obtain permit. According to one of them:

Nigeria is not organized. There is too much suffering in this country. When you get to Europe, you will not like to come back to this country. No, the difference is too much! The only problem is getting your paper and you can be sure that you can change your life positively if you are ready to work. It might be difficult the first time, but many people were able to stabilize later if they don't deport the person. If you asked many of us who came whether they will like to go back, the answer is yes, I can assure you (IDI/28/08/I5/male returnee from Belgium).

\section{Discussion of Findings and Policy Implications}

Irregular migration involves international migrants entering other nations' territories without official permission, sometimes through perilous routes. This phenomenon has generated serious public concern in view of the detrimental consequences, particularly for the irregular migrants who continue to endanger their lives (Bloch \& Chimienti 2012, Pennington \& Balaram 2013, IOM 20I5). Many developing nations tend to consider their nationals abroad as agents of national transformation and look up to them for remittances and to return with new skills to aid development efforts at home (Levitt \& Lamba-Nieves 20I3). The present article is an attempt at in-depth understanding of irregular migration and coping strategies of irregular migrants among Nigerian irregular returnees.

Findings from the study revealed that irregular migration in Nigeria takes a number of forms with 
many irregular migrants disguising as tourists, students, conference attendees; or by entering into dubious marriage contract with citizens of envisaged destination country. These modes involve tendering forged documents under these guises to obtain official permission. They are said to be associated with more cost and consist of traveling by air. Another means is to transverse complex routes by land, especially across the Maghreb to Europe. These routes tend to endanger the lives of irregular migrants in terms of deaths, exploitation, deportation and destitution that characterize the movement.

Furthermore, lack of employment opportunities surfaced prominently from the responses as reason for migration. Some of the study participants noted that they travelled because they could not get job after graduating from school. This point has been noted elsewhere (UNDP 2009, Bloch \& Chimienti 20I2, FRN 20I3). It however raises question on the motivating factors of irregular migration among those with good employment before migrating or migrants from established socio-economic background.

It was found that many irregular migrants are unable to live a settled life because of the irregular situation they are faced with. Thus, some engage in different kinds of menial and underground jobs to cope. Very often, these jobs are not stable and tend to expose irregular migrants to threats and exploitations by dubious employers and middlemen who take advantage of the situation. Results also showed that many irregular migrants change their real names as a strategy to conceal their identities and evade scrutiny by immigration authority in host countries.

Similarly, it is assumed that international migration is intrinsically positive in relation to migrants' development in terms of skill acquisition, capital accumulation and overall improvement of migrants' wellbeing (Lucas 2005, Farrant et al. 2006). However, results from the study indicate that being able to acquire useful skill is a function of migrants' condition in destination country. Their irregular situation makes it extremely difficult to settle down: a necessity for skill acquisition. A similar finding had been documented elsewhere (Adepoju \& Van der Wiel 20I0).

In addition, the uncertainties that surround irregular migration had caused many irregular migrants to lose substantial amount of money. Some revealed that their families borrowed money or sold their properties to raise fund for the travel with the hope to reimburse the source from remittances, but were unable to pay back. There were instances to suggest that some were able to send remittances, but a substantial part of it was mismanaged. In all events, perceptions of returnees on homecoming painted a gloomy picture of origin condition, and many revealed that they would re-migrate if they have the opportunity.

\section{Recommendations}

In view of the foregoing, this article is presenting the following recommendations as a way forward towards the mitigation of irregular migration in Nigeria.

I. Information on various migrant programmes organized by different industrialized countries should be made available to the public to enable interested and qualified prospective migrants to take advantage of such opportunities instead of resorting to illegitimate means.

2. In view of the high propensity of Nigerians to emigrate, efforts should be made by the government to establish a formal structure to aid Nigerians migrating to other countries. Such structure can provide pre-departure training and counseling to prepare migrants better for what they are likely to meet in the destination country. Currently, nothing of such exists in Nigeria despite the high outflow of migrants.

3. There are indications from the study's findings that the mode of return for many returnees is involuntary involving deportation or repatriation. In some cases, some level of physical force or even violence is employed (Global Migration Group [GMG] 20II). Anecdotal evidence gleaned from returnees suggests that deportation is often enforced with brutality that leaves migrants materially, socially, psychologically and economically wounded. No opportunity is given to take what legitimately belonged to them. Often, this afflicts them severely and makes them sink deeper in socio-economic miseries. To this end, there is need for Nigeria to enter into bilateral and multilateral agreements with host countries on the management of migration and deportation processes. Government should pursue policies aimed at protecting both migrants that are lawful residents and those in irregular situation in foreign lands. This will help to optimize the benefits of international migration and guarantee the human rights and dignity of all persons.

\section{Conclusion}

This study investigated the dynamics of irregular migration among irregular returnees in Lagos, Nigeria. It aimed to understand the determinants and coping strategies of irregular migrants in destination places with a view to clarifying certain misconceptions on the nexus between international migration and human development. While it may be argued that regular international migration might have development implications for migrants and 
homeland development, the same cannot be said with a conclusive tone on irregular migration. The study showed that migrants in irregular status in destination countries tend to be in a state of conflict with immigration law which is not conducive to the acquisition of useful skills. Thus, their contribution to homeland development is difficult to measure because many returned without any form of improvement in terms of skill acquisition and capital accumulation. A significant number of irregular migrants raised fund by mortgage and borrowing to make the move with the hope of paying back through remittances. However, there is evidence to indicate that many were unable to get sustainable job and regularize their stay before they returned, and ended up as defaulters with its social and economic consequences. In view of this, the study suggested some recommendations among which is the need for the establishment of a formal training structure to provide some form of pre-departure counseling to educate prospective migrants on the consequences of irregular migration. It is hoped that due consideration of these recommendations will help towards a better management of international migration in Nigeria.

All said, it should be noted that the fact that the study was mainly qualitative with a limited number of respondents posed some limitations on the findings. Thus, the findings cannot be generalized. However, they share important insights on some aspects of irregular migrants.

\section{References}

Abreu, A. (2010): The new economics of labour migration: Beware of neoclassicals bearing gifts, in Association for Social Economics. Retrieved from http/www.springerlink.com/349009. 26 July, 2015.

Adepoju, A. \& Van der Wiel, A. (2010): Seeking greener pasture abroad. Ibadan: Safari Books Ltd.

Adepoju, A. (20/0): Introduction: Rethinking the dynamics of migration within, from and to Africa, in Adepoju, A. (ed.) International migration: Within, to and from Africa in a globalised world. Legon-Accra, Ghana: Sub-Saharan Publishers. Pp. 9-44.

Bertoli, S. (2008): The impact of migration on poverty in Ecuador: Erring on the side of excessive optimism? Paper Presented at the Migration and Development Conference, Lille, France. November, 2008.

Bloch, A. \& Chimienti, M. (20I2): Irregular migration in a globalizing world, in Bloch, A. \& Chimienti, $M$. (eds.). Irregular migrants: Policy, politics, motives and everyday lives. Oxon, New York: Routledge, pp. 16-32.
Campbell, B. \& Barone, L. (20|2): Evolutionary basis of human migration, in Crawford, M. \& Campbell, B. (eds.) Causes and consequences of human migration: An evolutionary perspective. New York: Cambridge University Press. Pp. 45-65.

Castaneda, H. (20l4): Migrant male sex workers in Germany, in Minichiello, V. \& Scott, J. (eds.) Male sex work and society. New York: Harrington Park Press. Pp. 396-425.

De Haas, H. (2008): "Migration and development: A theoretical perspective". International Migration Review, 44 (I): 227-264.

Eborka, K (20|4): "Development impact of return migration in Nigeria: Myth or reality?" Irinkerindo: A Journal of African Migration (IJAM), Issue 7, January 2014 (www.africamigration.com).

Farrant, M., MacDonald, A. \& Sriskandarajah, D. (2006): Migration and development opportunities and challenges for policymakers. Research Series, no. 22. International Organization for Migration (IOM).

Federal Republic of Nigeria (20I3): Labour migration policy for Nigeria. Abuja: Ministry of Labour and Productivity. Revised Edition.

Gilbson, J., Mckenzie, D. \& Stillman, S. (2009): The Impact of International Migration on Remaining Household Members. World Bank's Policy Research Working Paper, Vol. 4956. New York: World Bank.

Global Migration Group (20l I): Migration for development: A bottom-up approach. A Handbook for practitioners and policymakers. Retrieved from www.globalmigrationgroup.org/en/migration-anddevelopment.

Gray, C.L. (2009): Rural Out-Migration and Smallholder Agriculture in the Southern Ecuadorian Andes. Population Environment. No. 30. Pp. 193-217.

IOM (International Organization for Migration) (20I I): Harnessing the potential of migration and return to promote development. Migration Research Series. No. 5. Geneva: IOM.

IOM (International Organization for Migration) (2012): Migrants caught in crisis: The IOM experience in Libya. Geneva: IOM.

IOM (International Organization for Migration) (2015): Mediterranean migrant death toll: As it happened. Retrieved online via: www.telegraghs.co.uk/news, on August, 17, 2015.

Iversen, V. (2005): Segmentation and social network multipliers in rural-urban migration. Development Research Centre on Migration, Globalization and Poverty. Working Paper, No. 9. 
Jokisch, B. (2002): "Migration and agricultural change: The case of smallholder agriculture in highland Ecuador". Human Ecology. 30 (4):523-550.

Kalu, K. (2008): Migration and institution building in Africa: Lessons from the Lagos plan of action, in Falola, T. \& Okpeh, O. O. (eds.) Population movements, conflicts and displacements in Nigeria. Asmara, Eritrea: Africa World Press. Pp. 133-153.

Lee, E. (1966): "A theory of migration". Demography, 3(I), 47-57.

Levitt, P. \& Lamba-Nieves, D. (20/3): Bringing culture back in: Opportunities and challenges from the Migration-development nexus, in Cortina, J. \& Ochoa-Reza, E. (eds.) New Perspectives in International Migration and Development. New York: University of Colombia Press, pp. 67-92.

Lucas, R. E. B. (2005): International migration and economic development: Lessons from lowincome countries. UK: Edward Elgar Publishing Inc.

Mai, N. (2007): Errance, migration and male sex work. In Ossman, S. (ed.) Places we share: Migration, subjectivity, and global mobility. Lanham, MD: Lexinton Books. Pp. 97-II9.

Maja-Pearce, A. (2009): The desert warriors. The News, p. 43.

Mayr, K. \& Peri, G. (2008): Return migration as a channel of brain gain. National Bureau of Economic Research (NBER) Working Paper No. I4039. May 2008.

Miluka, J.; Carletto, G.; Davis, B. \& Zezza, A. (2007): The vanishing farms: The impact of international migration on Albanian family farming. World Bank Policy Research Working Paper. Washington D.C.

Oucho, J. (20l0): African brain drain and gain, Diaspora and remittance: More rhetoric than action, in Adepoju, A., Van Naerssen, T. \&
Zoomers, A. (eds.) International migration and national development in sub-Saharan Africa. Netherlands: Brill. Pp. 49-69.

Pennigton, J. \& Balaram, B. (20/3): Homecoming: return and reintegration of irregular migrants from Nigeria. Institute for Public Policy Research, London.

Ravenstein, E. (I889): The laws of migration. Journal of the Statistical Society of London, 52(2), 24I305.

Sassen, S. (|99|): The global city: New York: Princeton University Press.

United Nations (200l): Population, environment and development: The Concise Report. Department of Economic and Social Affairs / Population Division. New York.

United Nations Development Programme (2009): Migration and human development: Opportunities and challenges. National Human Development Report, Armenia.

United Nations (20/0): Report on international migration. United Nations Population Division. New York.

UNODC (United Nations Office on Drug and Crime) (2009). Organized crime and irregular migration from Africa to Europe. Vienna.

Van de Valk, L. (20I0): Research in social work on coping and migration: Coping strategies of migrant generations of rural Moroccan and Muslim background in the Netherlands. Department of Social Work, School of Professional Education of Amsterdam, Netherlands.

World Bank (2007): The World Bank Research Programme 2005-2007: Abstract of Current Studies. Washington: World Bank.

World Bank (20/3a): Migration and Remittances Factbook. World Bank, Washington DC.

\section{Appendix I}

Table I. Socio-demographic Characteristics of Respondents

\begin{tabular}{|l|l|l|l|}
\hline Characteristics & Male & Female & Total \\
\hline Age Group & & & \\
$20-29$ & 4 & 6 & 10 \\
$30-39$ & 9 & 4 & 13 \\
$40-49$ & 8 & 4 & 12 \\
$50>$ & 2 & 1 & 3 \\
Total & 23 & 15 & 38 \\
\hline Level of Education & & & 20 \\
Secondary & 8 & 12 & 18 \\
Tertiary & 16 & 2 & 38 \\
Total & 24 & 14 & 19 \\
\hline Marital Status & 12 & 7 & \\
Single & & & \\
\hline
\end{tabular}


African Population Studies Vol. 30, No. 2,(Supp.),2016

\begin{tabular}{|l|l|l|l|}
\hline Married & 7 & 3 & 10 \\
Separated & 3 & 4 & 7 \\
Divorced & - & 1 & 1 \\
Widowed & I & - & 1 \\
Total & 23 & 15 & 38 \\
\hline Geopolitical Region & 7 & 2 & \\
South-west & 9 & 11 & 9 \\
South-south & 5 & 2 & 20 \\
Southeast & 2 & - & 7 \\
North-central & 23 & 15 & 2 \\
Total & & & 38 \\
\hline Destination Country & 6 & 3 & 16 \\
Western Europe & 2 & - & 2 \\
North America & 3 & 1 & 4 \\
Eastern Europe & 3 & 2 & 5 \\
Southern Africa & 5 & 5 & 10 \\
North Africa & 1 & - & 1 \\
Western Asia & 3 & 4 & 7 \\
Southern Europe & 23 & 15 & 38 \\
Total & & \\
\hline
\end{tabular}

Source: (field survey by authors). 